\title{
Recognition Assessment and Structural Equation Model of Participants after Learning Floral Design Courses as Vocational Education
}

\author{
Jin Suk Chu ${ }^{1,2}$, Inhea Kim², and Keun Young Huh ${ }^{1,2}$ * \\ ${ }^{1}$ Department of Landscape Architecture, Gyeongnam National University of Science and Technology, Jinju 52725, Korea \\ ${ }^{2}$ International Garden Institute, Gyeongnam National University of Science and Technology, Jinju 52725, Korea
}

\begin{abstract}
Despite the number of vocational programs for florists, florists are still considered to be hobbyists rather than specialized professionals in horticulture. The lack of a practical, unified vocational education system prevents the field from being specialized. The purpose of this study is to assess the participants recognition and analyze the structural equation model (SEM) of floral design courses to improve the direction of floral design education. Participants, the majority of whom were women in their 40s and 50s, filled out questionnaires regarding their experience with vocational education programs. Collected data showed high satisfaction with education, intent to persist in education, and attitude towards education. In the SEM analysis, the education satisfaction of participants improved as they increased their understanding of horticulture and aesthetics, learned specialized job skills, and obtained helpful certificates. The intent to persist in education is improved as the education satisfaction is improved. In addition, as the education satisfaction and intent to persist in education continue to improve, the attitude towards education becomes stronger, directly or indirectly. Thus, it is necessary to enhance technical education and aesthetics to improve the satisfaction, intent to persist, and attitude. Also horticultural therapy, producing wedding, funeral arrangements, etc., and flower/garden culture education need to be added to the education contents for expanding the scope of business.
\end{abstract}

Keywords: attitude, florist, horticultural therapy, intent to persist, satisfaction

\section{Introduction}

Floral design is commonly used in daily life as a technique of improving the function and aesthetic efficiency of space by utilizing plants as a main material and a human's creativity and expressive power (J.S. Kim, 2015). Vocational areas associated with floral design include activities required to commercialize products that are produced through horticultural activities using plants from designing to maintenance to sale, that is, areas of aesthetics, horticulture and management (Seo, 2014). As economic development and changes in lifestyle result in an increase in the demand for floral design, floral designers gain attention as a lifelong job in which people can display their individual characteristics regardless of their age and gender (J.S. Kim, 2015). To meet the trend, colleges open related courses and departments, and many educational 
institutions such as lifelong education centers have been established. The Human Resources Development Service of Korea created certified exams such as Craftsman Floral Design in 2004 and Engineer Floral Design in 2005.

Systematic and professional education programs need to be provided in order to recognize floral design as a specialized field. However, Seo (2014) pointed out that floral design has long been recognized as a specialized field apart from leisure and hobby activities, but that its educational system still remains as that for hobby activities. Lee (2005) and Park (2003) also said that a broad range of skills and knowledge related to horticulture and floral design is required for floral designers to become a specialist, but that the current floral design education programs failed to fully meet the demand for the knowledge and skills required in the industry. Han (2007) also pointed out that several organizations related to floral design have issued certificates based on different criteria and have provided education programs that lack unity, practicality and popularity across the country. Ok (2008) said that most of the education programs that have long been provided for floral designers have focused only on addressing commercial issues, but have failed to provide systematic education for professional vocation. Seo (2014) reported that floral design education in Korea puts more focus on aesthetics and relatively less focus on management than that in the United States, the United Kingdom and Germany, and that activities of floral designers in other countries are mainly involved in commercialization and sale while those in Korea are more like artistic activities. Many earlier studies pointed out issues associated with floral design education from various perspectives. Against this backdrop, this study aimed to suggest directions for improving floral design education as vocational education from the aspect of consumers. Specifically, a survey was conducted on those who had an experience of participating in floral design education as vocational education in order to assess their recognition about floral design education, and identify areas that need to be improved and expanded. In addition, all-round education from basic education programs to professional reeducation programs needs to be provided for floral designers to have professional ability, and the continuous engagement of participants is also required. In line with that, the structural equation model of satisfaction with education, intent to persist in education, and attitude towards education was analyzed.

\section{Methods}

\section{Theoretical Background}

\section{Characteristics of floral design education}

Seo (2014) defined floral design, based on the basic concept of 'design using plants,' as a 'skill of understanding the process of producing and distributing plants with aesthetic and ornamental values, and producing, maintaining, managing and selling products or works that have formative values in consideration of the natural beauty and the temporal (short and long-term) and spatial (indoor and outdoor) characteristics of plants,' and said that floral design involves several academic areas including aesthetics, horticulture and management. Seo (2014) also pointed out that the share of education on aesthetics is relatively higher than that of management, while horticulture or management focuses more on theoretical education than on practices, and thus that structures for practical education need to be established. Park et al. (2015) defined the job of 'floral design' as a 'job of planning, designing, producing, installing and maintaining floral decorations utilizing natural and artificial materials to meet customers' demands and the trends of the time and society according to the purpose and necessity of indoor and outdoor spaces, and thus creating aesthetic, functional and ecological values.'

Seo (2014) pointed out that the current education system for floral design is still confined within that for leisure education. Moon et al. (2010) said that there is no systematic and professional education program designed to nurture professional floral designers, and that systematic educational contents that integrate theoretical and practical knowledge together are required. Lee (2005) and Park (2003) said the current education programs on floral design do not fully 
accommodate knowledge and skills required in industrial settings. Han (2007) also pointed out that several organizations related to floral design have issued certificates based on different criteria and have provided education programs that lack unity, practicality and popularity across the country. Ok (2008) said that systematic education for professional vocation has been hardly provided. Park et al. (2015) pointed out that the current education programs focus on commercialization and vocational education only, lacking professionalism and unity.

\section{Correlation between satisfaction, intent to persist and attitude}

Persisting in educational courses is very important. Lee and Hwang (2013) said that reeducation programs must be provided in order to ensure participants have professional ability in the process of participating in basic education and specialized reeducation programs. It was also reported that the awareness of the necessity of reeducation, satisfaction with education, etc. ultimately has a positive effect on faithful attitudes towards duties. Satisfaction with education is a state of mind that a person feels when realizing his or her goal and satisfying his or her expectation after completing a course and a standard for judgement, serving as an important indicator that shows a subjective reaction to the satisfaction of a learner's demands (Song, 2013). In line with the achievement of educational goals, satisfaction with education is also an important factor for knowledge acquisition, which occurs when a learner is satisfied with education contents, feels his or her job competence has improved, assimilates and integrates what he or she learned and thus learns effectivity (Tan et al., 2003). Intent to persist in education is a learner's intentional reaction to persistently or continuously participate in education in order to achieve his or her purpose (Shin, 2003). Intent to persist in education is an important variable that affects learning and is utilized as a basic indicator that shows a learner's reaction after completing a class or education program (Shin, 2003). Depending on a learner's satisfaction, it interacts with intent to recommend, changes in attitude and complaining behaviors (Oliver, 1981). Attitude is a key factor that determines behaviors, having a direct and dynamic impact on behaviors (Yu, 2014). As Secord and Backman (1969) suggested, attitude is composed of cognitive, affective and behavioral components, and these three components are interconnected, forming a certain structure. Of the three components, the affective component has the biggest impact on the intensity and persistency of attitude (Yu, 2014), and it is strongly associated with assessing an object (Lee et al., 2012).

Kim and Yang (2010) and Yang (2010) said that education contents have a positive (+) impact on a participant's satisfaction with education which, in turn, has a positive (+) relation with intent to recommend. Cha and Park (2016) and Yoo et al. (2017) suggested that satisfaction with education and intent to persist in education are positively (+) correlated. C. Kim (2015) suggested that satisfaction with education can affect intent to persist in education. Levy (2007) reported that the higher a learner's satisfaction with education, the higher his or her intent to persist in learning. Oliver (1981) said that intent to persist in education is a behavior induced by a learner's satisfaction, and interacts with his or her intent to recommend, changes in attitude, complaining behaviors, etc. Attitude is a key factor that determines behaviors, and its affective component has the biggest impact on the intensity and persistency of attitude (Secord and Backman, 1969; Yu, 2014). The affective component is strongly associated with assessing an object (Lee et al., 2012). Therefore, it can be concluded that attitude has a positive (+) relation with satisfaction with education and intent to persist in education.

\section{Questionnaire Analysis for Recognition Assessment}

This study was conducted on those who had an experience of participating in floral design education as vocational education. To select subjects for this study, a question that asks whether respondents had an experience of participating in floral design education was included in the questionnaire developed in this study. Out of a total of 152 respondents, 128 
respondents answered that they had the experience, and their answer sheets were analyzed. Assuming that their motives for participating in floral design education differ, cluster analysis was carried out based on 6 questions on 'motive for participation' included in the questionnaire. A total of 89 respondents who participated in education to achieve economic goals, that is, goal-oriented learners, were selected as the final subjects (Houle, 1961; Jung and Lee, 2017; Yang, 2017).

The questionnaire used in this study includes one question on experience in participating in education, and 6 questions on motives for participation as shown in Table 1. The socio-demographic background of respondents were analyzed using 7 questions on their gender, age, education, learning duration, income, certificate and vocation. To assess their attitude towards education and satisfaction with education, 4 and 10 questions respectively were included, and 2 questions on intent to persist in education were included (Heo et al., 2016; Kim et al., 2016; Lee et al., 2016). To analyze the subjects' demands for improving the education contents and subjects, 7 and 8 questions respectively were included (Heo et al., 2017). Lastly, 9 questions on areas in which they are interested regarding the expansion of education contents were also included. Collected data were analyzed using IBM SPSS Statistics 24.

\section{Questionnaire Analysis for Structural Equation Model: Research Hypotheses and Modeling}

The following hypotheses were established in this study: "Satisfaction with education has a significant and positive $(+)$ impact on intent to persist in education $\left(\mathrm{H}_{1}\right)$ " and "Intent to persist in education has a significant and positive (+) impact on attitude towards education $\left(\mathrm{H}_{2}\right)$ " (Table 2). Subjects were selected using the same questionnaire analysis method for the assessment of recognition. Data used in structural equation model analysis were measurement variables - among the data collected through the questionnaire survey for the assessment of recognition - related to the operational definition of latent factors obtained through factor analysis and reliability analysis (Table 3). The research model developed to define the relations between latent factors and measurement variables is as shown in Figure 1, and it was statistically analyzed using IBM SPSS Amos 24 (Kim and Huh, 2016; Lee et al., 2017).

Table 1. Scheme of questionnaire design

\begin{tabular}{llc}
\hline & Category & No. of questions \\
\hline Selection of the questionnaires to meet the goal & Experience of participating in courses & 1 \\
\cline { 2 - 3 } Socio-demographic background & Motivation to participate in the courses & 6 \\
\hline Attitude towards education & & 7 \\
\hline Satisfaction with education & 4 \\
\hline Intent to persist in education & 10 \\
\hline Demand for the improvement of the education contents & 2 \\
\hline Demand for the improvement of the subjects & 7 \\
\hline Interest area to expand in the courses & 8 \\
\hline
\end{tabular}

Table 2. Conceptual framework development of participants recognition after learning floral design courses as vocational education: satisfaction, intent to persist, and attitude

Relation of factors Supporting literature

Satisfaction $\rightarrow$ Intent to persist $\quad$ Cha and Park (2016), C. Kim (2015), Kim and Yang (2010), Levy (2007), Yang (2010), Yoo et al. (2017)

Intent to persist $\rightarrow$ Attitude $\quad$ Lee and Hwang (2013), Lee et al. (2012), Secord and Backman (1969), Yu (2014) 
Table 3. Latent factors and variables in the theoretical model of participants recognition after learning floral design courses as vocational education

\begin{tabular}{|c|c|c|}
\hline Latent factor & Variable & Supporting literature \\
\hline Satisfaction (SA) & $\begin{array}{l}\text { - It helped you acquire job skills (x1) } \\
\text { - It helped improve your understanding of aesthetics (x2) } \\
\text { - It helped improve your understanding of horticulture (x3) } \\
\text { - It helped you obtain a certificate (x4) }\end{array}$ & $\begin{array}{l}\text { Cha and Park (2016), J.S. Kim (2015), Lee (2005), } \\
\text { Levy (2007), Moon et al. (2010). Ok (2008), Park } \\
\text { (2003), Park et al. (2015), Seo (2014), Tan et al. } \\
\text { (2003), Yoo et al. (2017) }\end{array}$ \\
\hline Intent to persist (IN) & $\begin{array}{l}\text { - I am intent on persisting in the courses (x5) } \\
\text { - I will recommend the courses to people nearby (x6) }\end{array}$ & $\begin{array}{l}\text { Cha and Park (2016), Jung and Lee (2017), C. Kim } \\
\text { (2015), Kim and Yang (2010), Levy (2007), Shin } \\
\text { (2003), Oliver (1981), Yang (2010), Yoo et al. (2017) }\end{array}$ \\
\hline Attitude (AT) & $\begin{array}{l}\text { Necessity of the education program to get a job in the } \\
\text { field of floral design (x7) } \\
\text { - Value of the education program compared to other } \\
\text { horticulture/floriculture education programs (x8) } \\
\text { - Importance of the education program to develop Korean } \\
\text { horticulture/floriculture (x9) }\end{array}$ & $\begin{array}{l}\text { Lee and Hwang (2013), Lee et al. (2012), Secord and } \\
\text { Backmand (1969) }\end{array}$ \\
\hline
\end{tabular}

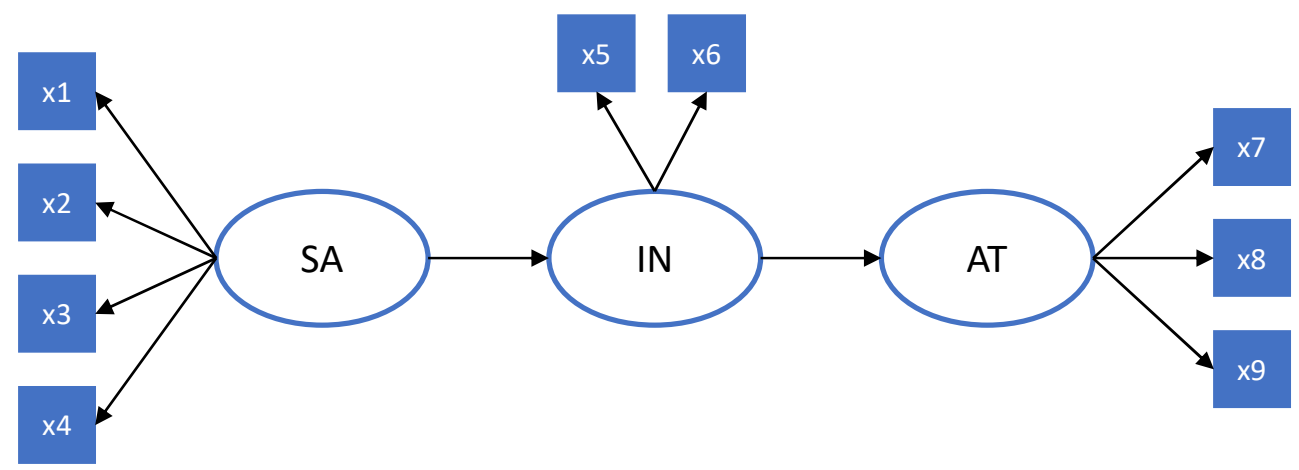

Figure 1. A theoretical model of participants recognition after learning floral design courses as vocational education. SA=Satisfaction; IN=Intent to persist; $A T=$ Attitude.

\section{Results and Discussion}

\section{Socio-demographic Backgrounds}

The share of male and female respondents was $9.0 \%$ and $91.0 \%$ respectively (Table 4), which indicates that most of the consumers of education or participants are female. The share of those in their 50s was the highest (39.3\%), followed by those in their 40s (30.3\%) and those in their 20s (20.2\%). Considering the fact that those in their 40s and 50s accounted for $69.6 \%$, most of the participants seem to have participated in courses provided by lifelong education centers, and some participants had the experience in college. In terms of education, those who graduated from university or college accounted for $71.3 \%$, followed by high school graduates (17.2\%). Those who learned floral design for over 3 years accounted for $37.9 \%$, followed by $1-2$ years (19.5\%). Given their education and learning duration, many respondents seem to have additionally attended floral design courses after graduating from university or college or during education. Their income (their spouse's income was excluded) was surveyed, and the share of those who earned 1-2 million won was the highest (29.1\%), followed by less than 1 million won (26.6\%), and 2-3 million won (21.5\%). Out of the respondents, a total of 45 persons were found to work in areas related to floral design, and those who earned 2-3 million won accounted for $31.1 \%$ of them, followed by 1-2 million won (28.9\%). Meanwhile, those who earned less than 1 million won out of 34 
Table 4. Socio-demographic background of respondents: gender, age, education, learning duration, and income

\begin{tabular}{|c|c|c|c|}
\hline Variable & & Frequency & Percent $(\%)$ \\
\hline \multirow{3}{*}{ Gender } & Male & 8 & 9.0 \\
\hline & Female & 81 & 91.0 \\
\hline & Total & 89 & 100.0 \\
\hline \multirow{7}{*}{ Age } & 19 and under & 0 & 0.0 \\
\hline & $20 \mathrm{~s}$ & 18 & 20.2 \\
\hline & $30 \mathrm{~s}$ & 5 & 5.6 \\
\hline & $40 \mathrm{~s}$ & 27 & 30.3 \\
\hline & $50 \mathrm{~s}$ & 35 & 39.3 \\
\hline & $60+$ & 4 & 4.5 \\
\hline & Total & 89 & 100.0 \\
\hline \multirow{4}{*}{ Education } & High school & 15 & 17.2 \\
\hline & College/University & 62 & 71.3 \\
\hline & Postgraduate school & 10 & 11.5 \\
\hline & Total & 87 & 100.0 \\
\hline \multirow{7}{*}{ Learning duration } & Less than 3 months & 3 & 3.4 \\
\hline & 3-6 months & 8 & 9.2 \\
\hline & 6-12 months & 11 & 12.6 \\
\hline & $1-2$ years & 17 & 19.5 \\
\hline & $2-3$ years & 15 & 17.2 \\
\hline & Over 3 years & 33 & 37.9 \\
\hline & Total & 87 & 100.0 \\
\hline \multirow{7}{*}{ Income $^{\mathrm{z}}$} & Less than one million won & $21(8)^{y}(13)^{x}$ & $26.6(17.8)(38.2)$ \\
\hline & 1-2 million won & $23(13)(10)$ & 29.1 ( 28.9) ( 29.4) \\
\hline & 2-3 million won & $17(14)(3)$ & $21.5(31.1)(8.8)$ \\
\hline & 3-4 million won & $10(7)(3)$ & $12.7(15.6)(8.8)$ \\
\hline & 4-5 million won & $3(1)(2)$ & $3.8(2.2)(5.9)$ \\
\hline & Over 5 million won & $5(2)(3)$ & $6.3(4.4)(8.8)$ \\
\hline & Total & $79(45)(34)$ & $100.0(100.0)(100.0)$ \\
\hline
\end{tabular}

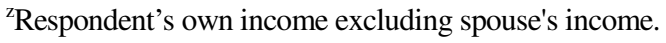

${ }^{\mathrm{y}}$ In floral design business, respondent's own income excluding spouse's income.

${ }^{\mathrm{x}}$ In other business, respondent's own income excluding spouse's income.

respondents who work in other fields accounted for $38.2 \%$, followed by $1-2$ million won (29.4\%). The results indicate that the income of female respondents who are professional floral designers is higher than that of other females respondents who work in other fields.

To the questions about certificate and vocation, respondents were allowed to choose multiple answers, and frequency analysis was performed. Those who have more than one certificate accounted for $58.4 \%$, and those who have more than 2 certificates accounted for $29.2 \%$. The share of those who hold the certificate of Craftsman Floral Design was the highest (31.5\%), followed by Engineer Floral Design (16.2\%) and Grade-2 Horticultural Therapist (11.5\%) (Table 5). Those who have more than 2 jobs accounted for $18.0 \%$. The share of florists was the highest (34.2\%), followed by floral design instructors (10.5\%) and flower coordinators (5.3\%).

\section{Assessment of Participants Recognition}

In terms of motives for participation, the score of "to obtain certificates," "for start-up or employment" and "to improve the quality of life through hobby, health, self-improvement,, etc." was very high (over 4.0), while the score of "for 
Table 5. Socio-demographic background of respondents: certificate and vocation

\begin{tabular}{|c|c|c|c|c|}
\hline & Variable & Frequency & Percent $(\%)$ & Percent of cases $(\%)$ \\
\hline & Craftsman floral design & 41 & 31.5 & 46.1 \\
\hline & Engineer floral design & 21 & 16.2 & 23.6 \\
\hline & Grade-2 horticultural therapist & 15 & 11.5 & 16.9 \\
\hline & Grade-1 horticultural therapist & 5 & 3.8 & 5.6 \\
\hline & Craftsman landscape architecture & 5 & 3.8 & 5.6 \\
\hline & Industrial engineer landscape architecture & 2 & 1.5 & 2.2 \\
\hline Certificate & Engineer landscape architecture & 0 & 0.0 & 0.0 \\
\hline & Urban agriculture manager & 2 & 1.5 & 2.2 \\
\hline & Craftsman horticulture & 1 & 0.8 & 1.1 \\
\hline & Industrial engineer plant protection & 0 & 0.0 & 0.0 \\
\hline & Engineer plant protection & 1 & 0.8 & 1.1 \\
\hline & No certificate & 37 & 28.5 & 41.6 \\
\hline & Total & 130 & 100.0 & 146.1 \\
\hline & Florist & 39 & 34.2 & 43.8 \\
\hline & Flower producer & 2 & 1.8 & 2.2 \\
\hline & Floral design lecturer & 12 & 10.5 & 13.5 \\
\hline & Green coordinator & 2 & 1.8 & 2.2 \\
\hline & Flower coordinator & 6 & 5.3 & 6.7 \\
\hline & Wedding coordinator & 2 & 1.8 & 2.2 \\
\hline & Gardener & 1 & 0.9 & 1.1 \\
\hline & Landscape architect & 1 & 0.9 & 1.1 \\
\hline & Student & 12 & 10.5 & 13.5 \\
\hline Vocation & Housewife & 12 & 10.5 & 13.5 \\
\hline & Office worker / civil servant & 4 & 3.5 & 4.5 \\
\hline & Educator & 5 & 4.4 & 5.6 \\
\hline & Professional / manager & 3 & 2.6 & 3.4 \\
\hline & Manufacturer & 2 & 1.8 & 2.2 \\
\hline & Worker in agriculture / forestry / fishery & 2 & 1.8 & 2.2 \\
\hline & Commercial / sales person & 1 & 0.9 & 1.1 \\
\hline & Service provider & 4 & 3.5 & 4.5 \\
\hline & Other & 4 & 3.5 & 4.5 \\
\hline & Total & 114 & 100.0 & 128.1 \\
\hline
\end{tabular}

non-profit social activities" was the lowest (3.5) (Table 6). Seo (2014) pointed out that the current education system is still confined within that for leisure education, but the motive of the respondents who participated in floral design education as vocational education is not only for getting a job, but also for leisure activities such as hobbies. Therefore, it will be necessary to balance vocational education and leisure education. The overall satisfaction with education contents was very high (4.0), but the score of "It helped improve your understanding of management" was the lowest (3.4). According to Lee (2005), Park (2003) and Seo (2014), the results can be attributed to people's recognition that floral design education is basically design education using horticultural plants, and the importance of aesthetic in floral design education is relatively higher than that of management. In terms of intent to persist in education, the score of "I am intent on persisting in the courses" and "I will recommend the courses to people nearby" was 4.3 and 4.2 respectively, which is attributable to the effect of high satisfaction with education (C. Kim, 2015). In terms of attitude, the score of "awareness of the courses," "necessity of the courses to get a job in the field of floral design," "value of the courses compared to other horticulture/floriculture courses" and "importance of the courses to develop Korean horticulture/floriculture" was over 
Table 6. Assessment of participants recognition after learning floral design courses as vocational education: motivation to participation, satisfaction, intent to persist, and attitude

\begin{tabular}{|c|c|c|c|}
\hline Category & Variable & Mean & Standard error \\
\hline \multirow{6}{*}{$\begin{array}{l}\text { Motivation to } \\
\text { participate in the } \\
\text { courses }\end{array}$} & To obtain certificates & 4.2 & .08 \\
\hline & For start-up or employment & 4.1 & .07 \\
\hline & To be a lecturer at university or continuing education center & 3.7 & .11 \\
\hline & For social activities of different economic purposes & 3.8 & .08 \\
\hline & For non-profit social activities & 3.5 & .09 \\
\hline & To improve the quality of life through hobby, health, self-development, etc. & 4.2 & .09 \\
\hline \multirow{10}{*}{$\begin{array}{l}\text { Satisfaction with the } \\
\text { education contents }\end{array}$} & It had a professional and original discipline & 4.0 & .08 \\
\hline & It had a systematic educational system & 3.8 & .08 \\
\hline & It helped improve your understanding of professional theory & 4.0 & .09 \\
\hline & It helped you acquire job skills & 4.2 & .07 \\
\hline & It helped improve your understanding of aesthetics & 4.1 & .08 \\
\hline & It helped improve your understanding of horticulture & 4.0 & .09 \\
\hline & It helped improve your understanding of management & 3.4 & .10 \\
\hline & It helped you obtain a certificate & 4.1 & .08 \\
\hline & It helped you launch a start-up or be employed & 3.9 & .08 \\
\hline & It is entirely satisfactory & 4.1 & .07 \\
\hline \multirow{2}{*}{$\begin{array}{l}\text { Intent to persist in the } \\
\text { courses }\end{array}$} & I am intent on persisting in the courses & 4.3 & .07 \\
\hline & I will recommend the courses to people nearby & 4.2 & .08 \\
\hline \multirow{4}{*}{$\begin{array}{l}\text { Attitude towards the } \\
\text { courses }\end{array}$} & Awareness of the courses & 4.1 & .10 \\
\hline & Necessity of the courses to get a job in the field of floral design & 4.5 & .08 \\
\hline & Value of the courses compared to other horticulture/floriculture courses & 4.4 & .08 \\
\hline & Importance of the courses to develop Korean horticulture/floriculture & 4.4 & .07 \\
\hline
\end{tabular}

Note. Response categories used a 5-point Likert scale (1=strongly disagree; 5=strongly agree).

4.0, and, in particular, the score of "necessity as vocational education" was 4.5, relatively higher than that of the rest answers (Secord and Backman, 1969).

Lee and Hwang (2013) pointed out that reeducation programs must be provided in order to ensure participants have professional ability in the process of participating in basic education and specialized reeducation programs. Therefore, it is necessary to improve satisfaction with education and intent to persist in education by improving education contents. Although satisfaction with education contents, except management, was about 4.0, the score of demands for improvements in education contents was very high (about 4.0) (Table 7). The score of "strengthen practical training (skills) for job" and "reinforce aesthetics (design) education" was the highest (4.1), while that of "reinforce education based on certification acquisition" was the lowest (3.8). The second lowest one was "reinforce professional theory education (3.9)." The overall score of demands for improvements in courses was high (over 3.5). The score of "floral design practice" was the highest (4.2), and that of "floral design and manufacture theory" and "floral ornaments manufacture" was also high (4.0). Meanwhile, the score of "floral material and morphology" was the lowest, and the score of both "flower quality maintenance and management" and "flower distribution and management" was low (3.8). Ok (2008) reported that there has been almost no systematic education for professional vocational education. Seo (2014) pointed out that the current education system is still confined within that of leisure education, that horticulture and management have focused more on theoretical education than practical training, and that an educational system for practical training has not been established. In order to improve satisfaction with education and intent to persist in education, it will be necessary to improve education contents and thus to strengthen education on vocational skills and aesthetics. Lastly, in terms of areas in which respondents are interested, the score of "horticultural therapy" and 
Table 7. Assessment of participants recognition after learning floral design courses as vocational Education: demand for the improvement of the education contents and subjects, and interest area to expand in the courses

\begin{tabular}{|c|c|c|c|}
\hline Category & Variable & Mean & Standard error \\
\hline \multirow{7}{*}{$\begin{array}{l}\text { Demand for the } \\
\text { improvement of the } \\
\text { education contents }\end{array}$} & Reinforce professional theory education & 3.9 & .09 \\
\hline & Strengthen practical training for job & 4.1 & .09 \\
\hline & Reinforce aesthetic (design) education & 4.1 & .08 \\
\hline & Reinforce horticultural education & 4.0 & .08 \\
\hline & Reinforce managerial education & 4.0 & .09 \\
\hline & Reinforce education based on certification acquisition & 3.8 & .10 \\
\hline & Reinforce education for start-up or employment & 4.0 & .09 \\
\hline \multirow{8}{*}{$\begin{array}{l}\text { Demand for the } \\
\text { improvement of the } \\
\text { subjects }\end{array}$} & Floral material and morphology & 3.7 & .08 \\
\hline & Flower quality maintenance and management & 3.8 & .09 \\
\hline & Floral decoration theory & 3.9 & .09 \\
\hline & Floral design and manufacture theory & 4.0 & .09 \\
\hline & Flower distribution and management & 3.8 & .09 \\
\hline & Graphic design (drawing) & 3.9 & .08 \\
\hline & Floral ornaments manufacture & 4.0 & .10 \\
\hline & Floral design practice & 4.2 & .09 \\
\hline \multirow{9}{*}{$\begin{array}{l}\text { Interest area to expand } \\
\text { in the courses }\end{array}$} & Horticultural therapy & 4.2 & .08 \\
\hline & Care farming or healing farming & 3.9 & .09 \\
\hline & Urban farming (allotment garden, community garden etc.) & 3.8 & .09 \\
\hline & Establishment and management of botanic gardens, arboretum etc. & 3.8 & .09 \\
\hline & Planning and operation of flower show, garden exhibition etc & 3.9 & .09 \\
\hline & Botanical illustration & 3.9 & .10 \\
\hline & Producing wedding, funeral arrangements etc. & 4.2 & .09 \\
\hline & Flower/garden culture education & 4.0 & .09 \\
\hline & Flower/garden tourism & 3.8 & .09 \\
\hline
\end{tabular}

Note. Response categories used a 5-point Likert scale (1=strongly disagree; $5=$ =strongly agree).

"producing wedding, funeral arrangements etc." was the highest (4.2), followed by "flower/garden culture education (4.0)." In addition, the score of the rest six areas was also high (over 3.5).

\section{Structural Equation Model of Participants Recognition}

\section{Confirmatory Factor Analysis}

Satisfactory combinations of measurement variables selected to develop a structural equation model were examined. The measurement model developed based on the results was converted into a structural model according to its theoretical model, and statistical analysis was carried out (Xu and Fox, 2014). The construction reliability of measurement variables on each latent factor limited by the operational definition in confirmatory factor analysis was over 0.7 as shown in Table 8 , which indicates that the measurement variables are internally consistent (Churchill and Peter, 1984).

The calculated AVE (average variance extracted) of all the latent factors (satisfaction with education, intent to persist in education, and attitude towards education) was over 0.5 as shown in Table 9, which indicates convergent validity. In other words, each measurement variable explains the latent variables well. The squared correlation coefficient of satisfaction with education, intent to persist in education and attitude towards education was lower than the calculated AVE of all the latent factors, which indicates discriminant validity between them (Fornell and Larcker, 1981). Since the operational definition of the latent factors (satisfaction with education, intent to persist in education and attitude) showed internal consistency between the measurement variables, as well as convergent validity and discriminant validity, the structural 
Table 8. Factor loading of the measurement model of participants recognition after learning floral design courses as vocational education

\begin{tabular}{|c|c|c|c|c|}
\hline Latent factor & Variable & Factor loading & Error variance & C.R. ${ }^{z}$ \\
\hline \multirow{4}{*}{ Satisfaction (SA) } & - It helped you acquire job skills (x1) & .754 & .186 & \multirow{4}{*}{.867} \\
\hline & - It helped improve your understanding of aesthetics (x2) & 657 & .307 & \\
\hline & - It helped improve your understanding of horticulture (x3) & .777 & .253 & \\
\hline & - It helped you obtain a certificate (x4) & .558 & .415 & \\
\hline \multirow{2}{*}{ Intent to persist (IN) } & - I am intent on persisting in the courses (x5) & 692 & .236 & \multirow{2}{*}{.884} \\
\hline & - I will recommend the courses to people nearby (x6) & .900 & .095 & \\
\hline \multirow{3}{*}{ Attitude (AT) } & - Necessity of the courses to get a job in the field of floral design ( $\mathrm{x} 7)$ & .744 & .222 & \multirow{3}{*}{.888} \\
\hline & $\begin{array}{l}\text { - Value of the courses compared to other horticulture/floriculture } \\
\text { courses (x8) }\end{array}$ & .885 & .122 & \\
\hline & $\begin{array}{l}\text { - Importance of the courses to develop Korean } \\
\text { horticulture/floriculture (x9) }\end{array}$ & .599 & .284 & \\
\hline
\end{tabular}

${ }^{\mathrm{z}}$ Construction reliability $=(\text { sum of standardized factor loadings })^{2} /\left[(\text { sum of standardized factor loadings })^{2}+(\right.$ sum of error variances $\left.)\right]$

Table 9. Squared Correlation value and Average Variance Extracted (AVE) of the latent variables

\begin{tabular}{lccc}
\hline \multicolumn{1}{c}{ Latent variable } & Satisfacton (SA) & Intent to persist (IN) & Attitude (AT) \\
\hline Satisfacton (SA) & $.623^{\mathrm{z}}$ & & .796 \\
Intent to persist (IN) & $.313^{* *}$ & $.522^{* *}$ & .730 \\
Attitude (AT) & $.399^{* *}$ & \\
\hline
\end{tabular}

${ }^{\mathrm{z}}$ Average variance extracted $(\mathrm{AVE})=[$ sum of (standardized factor loadings) 2$] /\left[\right.$ sum of $(\text { standardized factor loadings })^{2}+($ sum of error variances)]

${ }^{* *}$ Correlation is significant at the 0.01 level (2-tailed).

Table 10. Summary of outcomes for the hypotheses

\begin{tabular}{lc}
\hline \multicolumn{1}{c}{ Hypothesis } & Outcome \\
\hline $\mathrm{H}_{1}$ : Satisfaction has a significant and positive influence on Intent to persist. & Supported \\
$\mathrm{H}_{2}$ : Intent to persist has a significant and positive influence on Attitude. & Supported \\
\hline
\end{tabular}

model for testing was found to be a theoretical model that has a proper measurement model.

\section{Structural Model Analysis}

The structural equation model was analyzed, and the statistical value of $x^{2}$ of the theoretical model was 36.053 , $\mathrm{df}=25$, and $p=.071$, indicating that the model was fitted. In addition, when GFI (goodness of fit index), another model fitness, is over 0.90 , the model is recognized as a fitted model. The GFI of the developed model was 0.959 in this study. When RMR (root mean square residual) is lower than 0.05 , the model is recognized as a fitted model. The RMR of the developed model was 0.039. The AGFI (adjusted GFI) of a fitted model is over 0.9, but the AGFI of the developed model in this study was 0.854 . The NFI (normal fit index) of a fitted model is over 0.9 , but the NFI of the developed model was 0.883 . When NNFI (non-normal fit index) is over 0.9, the model is recognized as a fitted model. the NNFI of the developed model was 0.941 . When CFI (comparative fit index) is close to 1 , the model is recognized as a satisfactory model. The CFI of the developed model was 0.959. All the fitness indices, except the AGFI and NFI, showed satisfactory results (Bentler and Bonett, 1980; Kim, 2011). Therefore, the initially established theoretical model was adopted. As shown in Table 10, 


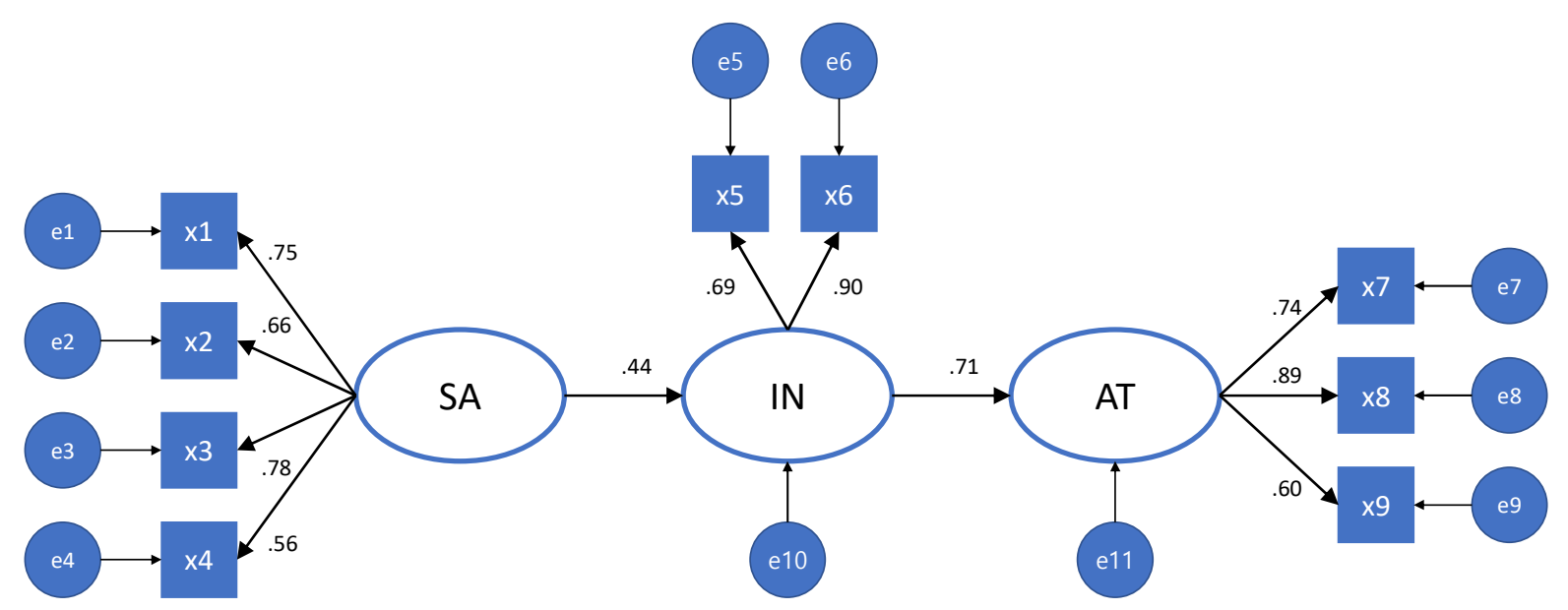

Figure 2. Structure model with path diagram: $x^{2}=36.053 ; \mathrm{df}=25 ; p=.071$; path coefficient $=$ standardized regression weight. SA=Satisfaction; IN=Intent to persist; $A T=A t t i t u d e$.

Table 11. Regression weights among satisfaction, intent to persist, and attitude of participants recognition after learning floral design courses as vocational education

\begin{tabular}{lccccc}
\hline & $\begin{array}{c}\text { Unstandardized } \\
\text { estimate }\end{array}$ & $\begin{array}{c}\text { Standardized } \\
\text { estimate }\end{array}$ & $\begin{array}{c}\text { Standard } \\
\text { error }\end{array}$ & Critical ratio & $p$-value \\
\hline Satisfaction $\rightarrow$ Intent to persist & .417 & .444 & .136 & 3.061 & .002 \\
Intent to persist $\rightarrow$ Attitude & .795 & .707 & .168 & 4.738 & .000 \\
\hline
\end{tabular}

Table 12. Standardized indirect effects and two tailed significance among satisfaction, intent to persist, and attitude of participants recognition after learning floral design courses as vocational education

\begin{tabular}{ccccc}
\hline & & Satisfaction & Intent to persist & Attitude \\
\hline \multirow{2}{*}{ Intent to persist } & Standardized indirect effect & .000 & .000 & .000 \\
\cline { 2 - 5 } & $p$-value & - & - & - \\
\multirow{2}{*}{ Attitude } & Standardized indirect effect & $.314^{*}$ & .000 & .000 \\
& Significance (2-tailed) & .010 & - & - \\
\hline
\end{tabular}

*Indirect effect is significant at the 0.05 level (2-tailed).

the following hypotheses were adopted: "Satisfaction with education has a significant and positive (+) impact on intent to persist in education $\left(\mathrm{H}_{1}\right)$ " and "Intent to persist in education has a significant and positive $(+)$ impact on attitude towards education $\left(\mathrm{H}_{2}\right)$." The structural equation model expressed with a path diagram and path coefficient is as shown in Figure 2.

The non-standardized and standardized regression coefficients between [satisfaction with education $\rightarrow$ intent to persist in education] were .417 and .444 respectively, and the $p$ value was found to be very significant $(p<.01)$. The non-standardized and standardized regression coefficients between [intent to persist in education $\rightarrow$ attitude] were .795 and .707 , and the $p$ value was found to be very significant $(p<.01)$ (Table 11). The statistical significance of indirect effects was tested using bootstrapping. The standardized indirect effect of [satisfaction with education $\rightarrow$ intent to persist in education $\rightarrow$ attitude] was .314 and the $p$ value was found to be significant ( $p<.05$ ) (Table 12). Therefore, satisfaction with education has a significant and positive (+) impact on intent to persist in education in a direct way, and has a significant and positive (+) impact on attitude towards education in an indirect way. Intent to persist in education has a significant and positive (+) impact on attitude towards education in a direct way. Kim and Yang (2010) and Yang (2010) reported that 
education contents has a positive (+) impact on satisfaction with education, and that satisfaction with education has a positive (+) relation with intent to recommend. Cha and Park (2016), C. Kim (2015) and Yoo et al. (2017) suggested that satisfaction with education has a significant and positive (+) influence on intent to persist in education. Lee et al. (2012) said that the affective component of attitude is strongly associated with assessing an object. These results are consistent with those of this study.

The results were comprehensively interpreted as follows. First, respondents who had an experience of attending floral design classes as vocational education were found to show a higher satisfaction with education when they felt that their understanding of horticulture and aesthetics among education contents improved, that they acquired vocational skills, and that the education was effective in acquiring certificates. Second, as satisfaction with education improved, intent to persist in education, that is, intent to continuously participate in and recommend floral design education to others, also improved. Third, as satisfaction with education and intent to persist in education improved, the intensity and persistency of attitude towards education became stronger in a direct or indirect way.

\section{Conclusion}

This study was conducted to suggest directions for improving floral design education as vocational education from the aspect of consumers. Specifically, a survey was conducted on those who had an experience of participating in floral design education as vocational education in order to assess their recognition about floral design education, and identify areas that need to be improved and expanded. In addition, a structural equation model on satisfaction with education, intent to persist in education, and attitude towards education was analyzed. The results of the survey on participants recognition were as follows. Out of the respondents, females accounted for $91.0 \%$, and those in their 40s and 50s accounted for 69.6\%. The respondents who participated in floral design education as vocational education were found to have participated in the education not only for finding a job, but also for leisure activities including hobbies. The overall score of satisfaction with education contents was very high (about 4.0), while that of satisfaction with management was the lowest (3.4). The score of intent to persist in education and attitude towards education was very high ( 4.3 and 4.4 respectively). The overall score of demands for the improvement of the education contents was very high (about 4.0), and that of demands for the improvement of the subjects was also high (over 3.5). In particular, the demand for strengthening education on skills (practical training) for jobs was high. In terms of areas in which respondents are interested, the score of "horticultural therapy" and "producing wedding, funeral arrangements, etc." was the highest (4.2), followed by "flower/garden culture education (4.0)."

Two hypotheses - "Satisfaction with education has a significant and positive (+) impact on intent to persist in education $\left(\mathrm{H}_{1}\right)$ " and "Intent to persist in education has a significant and positive $(+)$ impact on attitude towards education $\left(\mathrm{H}_{2}\right)$ " - and a structural equation model were established, and the model was analyzed. The statistical value of $x^{2}$ of the theoretical model was $36.053, \mathrm{df}=25$, and $p=.071$, indicating that the model was fitted. Other fitness indices also showed satisfactory results. Therefore, the two research hypotheses and model were adopted. As a result, respondents who have an experience of attending floral design classes as vocational education show a higher satisfaction with education when they feel that their understanding of horticulture and aesthetics among education contents improves, that they acquire vocational skills, and that the education is effective in acquiring certificates. As satisfaction with education improves, intent to persist in education also improves. In addition, as satisfaction with education and intent to persist in education improve, the intensity and persistency of attitude towards education become stronger in a direct or indirect way.

All-round education from basic education programs to professional reeducation programs needs to be provided for 
floral designers to have professional ability, and the continuous engagement of participants is also required. Therefore, it will be necessary to improve education contents and thus to strengthen education on vocational skills and aesthetics in order to improve satisfaction with education, intent to persist in education, and attitude. In addition, it will be also necessary to add horticultural therapy, producing wedding, funeral arrangements, etc., and flower/garden culture education to the education contents for expanding the scope of business.

\section{References}

Bentler, P.M. and D.G. Bonett. 1980. Significance tests and goodness of fit in the analysis of covariance structures. Psychol. Bull. 88(3):588-606. DOI:10.1037/0033-2909.88.3.588

Cha, S.B. and S.Y. Park. 2016. An analysis of the structural relationships among task value, social support, learning satisfaction, and persistence of learning in the cooperated program of an agricultural high school and industry. J. Agric. Educ. Hum. Resour. Dev. 48(2):1-23.

Churchill, G.A. and J.P. Peter. 1984. Research design effects on the reliability of rating scales: a Meta-Analysis. J. Mark. Res. 21(4):360-375. DOI:10.2307/3151463

Fornell, C. and D.F. Larcker. 1981. Evaluating structural equation models with unobservable variables and measurement error. J. Mark. Res. 18(1):39-50. DOI:10.2307/3151312

Han, S.H. 2007. A study on actual management status and activation plan of flower shops. Master's thesis, Kyung Hee University, Seoul, Korea.

Heo, H., I. Kim, E.J. Jo, K.Y. Huh, and J. Park. 2016. Analysis on residents recognition and preference for planning a natural recreation forest near city: focused on planning Mt. Wora natural recreation forest in Jinju city. J. Korean Soc. People Plants Environ. 19(6):639-647.

Heo, H.C., I. Kim, K.Y. Huh, and J.H. Park. 2017. Changes in frequency of use and satisfaction of visitors on urban forest as recreational resources-focused on Seonhaksan and Bibongsan mountains, Jinju city, Korea-. J. People Plants Environ. 20(6):639-651.

Houle, C.O. 1961. The inquiring mind. Madison, WI: University of Wisconsin Press.

Jung, M. and H. Lee. 2017. The effects of participation motivation for vocational education program of middle-aged female learners' on participation continuation intention and the mediating effects of educational satisfaction. J. Lifelong Learn. Soc. 13(2):109-133.

Kim, C. 2015. The effect that participating motives and involvement about lifelong education have on the learners' satisfaction, continuous intention to take courses, and recommendation intention. J. Korea Contents Assoc. 15(6):575-588.

Kim, J.M. and K.Y. Huh. 2016. Structure model analysis on visitors satisfaction of sightseeing in Mt. Keumwon arboretum. J. Korean Soc. People Plants Environ. 19(3):261-268.

Kim, J.S. 2015. Research on method of utilizing a floral designer's national technical qualification. J. Korean Soc. Flor. Art Des. 33:45-58.

Kim, K.S. 2011. Analysis of structural equation model. Seoul, South Korea: Hannarae Publishing Co.

Kim, M.S. and Y.S. Yang. 2010. The effects of embedding-study oriented entrepreneurship educating program on participants Satisfaction and Referring will. J. Korea Acad. Ind. Coop. Soc. 11(6):2004-2012.

Kim, Y.H., K.Y. Huh, and M.R. Huh. 2016. Characteristics analysis of visitors satisfaction and revisit intention on horticulture exhibition at a university campus. J. Korean Soc. People Plants Environ. 19(6):623-630.

Lee, J.H. 2005. Representation of floral exhibits for interior decoration using potted plants. Master's thesis, Yeungnam University, Gyeongbuk, Korea.

Lee, J.W., K.Y. Huh, and J. Park. 2016. Awareness and satisfaction of citizens on green roof projects (GRPs) in Changwon city, South Korea. J. Korean Soc. People Plants Environ. 19(6):605-614.

Lee, N., K.Y. Huh, and J. Park. 2017. A study on recognition and demands of forest interpretation programs: focused on 
Jinju city and Gyeongnam region. J. People Plants Environ. 20(4):395-405.

Lee, S. H., J.S. Kim, and K.H. Han. 2012. A study on effects that elementary school students' attitudes toward race have on multicultural values. J. Educ. Cult. 18(1):133-166.

Lee, Y.C. and H.S Hwang. 2013. A study on the reeducation program for volunteers: focused on effect factors among involvement, satisfaction and task commitment. J. Korea Policy Stud. 13(3):239-259.

Levy, Y. 2007. Comparing dropouts and persistence in e-learning courses. Comput. Educ. 48(2):185-204. DOI:10.1016/j.compedu.2004.12.004

Moon, H.S., W.H. Joung, K.W. Han, E.J. Jang, and C.H. Pak. 2010. An analysis of Korean floral design education program and the job satisfaction of florist and applicants florist. Flower Res. J. 18(4):315-322.

Ok, J.J. 2008. The study on the present condition of floristry education and the development of its Curriculum. Doctoral dissertation, University of Seoul, Seoul, Korea.

Oliver, R. 1981. Measurement and evaluation of satisfaction processes in retail settings. J. Retail. 57(3):25-48.

Park, H.N. 2003 A. comparative analysis a study on flower arrangement design between America and Germany. Master's thesis, Daegu University, Gyeongbuk, Korea.

Park, M.O., S.W. Han, and B.H. Koo. 2015. A study on the job standardization of floral design by analyzing flower industry fields. J. Korean Soc. Flor. Art Des. 33:3-23.

Secord, P.F. and C.W. Backman. 1969. Social Psychology. New York, NY: McGraw-Hill Education.

Seo, J.H. 2014. The review on the study of floristry's definition and education curriculum. J. Korean Soc. Flor. Art Des. 30:179-190.

Shin, N. 2003. Transactional presence as a critical predictor of success in distance learning. Distance Educ. 24(1):69-86.

Song, Y.H. 2013. The structural relationships among task value, academic burnout, learning satisfaction and persistence in an e-learning course. J. Lifelong Learn. Soc. 9(3):171-187.

Tan, J.A., R.J. Hall, and C. Boyce. 2003. The role of employee reactions in predicting training effectiveness. Human Resour. Dev. Q. 14(4):397-411. DOI:10.1002/hrdq.1076

Yang, M. 2017. Relationship among media education motivation, satisfaction, and intention to continuous participation. J. Korea Contents Assoc. 17(6):124-131.

Yang, Y.S. 2010. The effects of the quality of technology entrepreneurship educating program on participants satisfaction and referring will. J. Korea Acad. Ind. Coop. Soc. 11(3):1071-1078.

Yoo, M.S., K.H. Kwak, and S.J. Park. 2017. The effect of participation motivation and satisfaction on the participation persistence among adult learners at college continuing education center. J. Korea Acad. Ind. Coop. Soc. 18(12):414-422.

Yu, J.Y. 2014. The study on attitude toward other races and ethnics of Korean high school students. Soc. Stud. Educ. 53(1):41-59.

Xu, F. and D. Fox. 2014. Modelling attitudes to nature, tourism and sustainable development in national parks: a survey of visitors in China and the UK. Tour. Manag. 45:142-158. DOI:10.1016/j.tourman.2014.03.005 